\title{
Ecological niche and potential distribution of the endangered Bos javanicus in south-western Java, Indonesia
}

\author{
Dede Aulia Rahman ${ }^{1 *}$ \\ ${ }^{1}$ Department of Forest Resources Conservation and Ecotourism, Faculty of Forestry, IPB University Jl. Lingkar Akademik, Kampus \\ IPB Dramaga, Bogor, 16680, West Java Indonesia. Email: dede.auliarahman@gmail.com (DAR) \\ *Corresponding author
}

\begin{abstract}
Understanding the ecological niche and spatial distribution of wildlife species is important for the conserving and enhancing of biodiversity in a landscape system. Banteng (Bos javanicus) is a vital and important source of germplasm and protected by Indonesia law and considered to be Endangered under the International Union for Conservation of Nature list. During 2015 to 2017, surveys were undertaken on the largest population of wild banteng occurring in Ujung Kulon National Park. Data were gathered from a long-term camera trapping to assess the ecological niche and distribution of banteng using Maximum Entropy Modelling (Maxent) algorithm. Over a period of 30,149 trap/nights there were high photo rates, indicating areas of high conservation importance for these species within the park. Distribution prediction indicated that habitat variables such as secondary forest, predation by Cuon alpinus and human impacts such as cultivated area and illegal activity, are critical to determining the habitat use of banteng. The results showed that banteng within the national park, mainly used the centre areas of the park with similar spatial use, both in wet and dry seasons. This study provides essential documentation of large Bovidae distribution in one of the four remaining habitats on Java, information for the development of management strategies within the park, and a basis upon which to develop future research on banteng.

Entender el nicho ecológico y la distribución espacial para el manejo de especies de fauna silvestre es importante para conservar y mejorar la biodiversidad en el sistema de paisaje. El banteng (Bos javanicus) es una fuente vital e importante de germoplasma y especies protegidas por la ley de Indonesia y se considera en peligro de extinción en la lista de la Unión Internacional para la Conservación de la Naturaleza. En 2015 a 2017 se realizarón investigaciones sobre la mayor población de bantengs silvestres en el Parque Nacional Ujung Kulon. Los datos se obtuvieron mediante cámaras trampa se usaron para evaluar el nicho ecológico y la distribución del banteng, utilizando el algoritmo de Modelado de Máxima Entropía (Maxent). Durante 30,149 trampas/noches, las tasas de captura fotográfica fueron altas, lo que indica áreas de gran importancia para la conservación de estas especies en el parque. La predicción de la distribución indicó que las variables de hábitat como el bosque secundario, la depredación por Cuon alpinus y los impactos humanos, como el área cultivada y la actividad ilegal, son fundamentales para determinar el uso del hábitat del banteng. Los resultados mostraron que dentro del parque nacional el banteng utilizaba principalmente las áreas centrales, con un uso espacial similar, en las estaciones húmedas y secas. Este estudio proporciona documentación esencial sobre la importante distribución de grandes bóvidos en uno de los cuatro hábitats que quedan en Java. También proporciona información para el desarrollo de estrategias de manejo en el parque y una base sobre la cual desarrollar futuras investigaciones del banteng.
\end{abstract}

Key words: Banteng; camera trap; distribution; habitat use; Maxent.

(C) 2020 Asociación Mexicana de Mastozoología, www.mastozoologiamexicana.org

\section{Introduction}

Ujung Kulon is one of Indonesia's first national parks, and considered as biodiversity hotspot as well as a critical area for the preservation of medium-large mammals (Rahman et al. 2018). One of its most prominent mammals is the Endangered banteng (Bos javanicus). The species is protected by the Indonesian law (Attachment on Goverment Regulation No.7 of 1999 and Act No. 5 of 1990), listed on CITES Appendix I, and is one of the 25 species considered by the Indonesian government, in needs of special conservation attention (Ministry of Environment and Forestry Decree SK.180/IV-KKH/2015). The population of this species was believed to be limited to 905 individuals recorded in Ujung Kulon National Park in 1997, 15 individuals recorded in Baluran National Park in 2011, 100 individuals recorded in Alas Purwo National Park in 2011, and between 125 to 150 individuals in Meru Betiri National Park (Gardner et al. 2014). Regardless of its conservation status and its potential as an alternative future animal protein source, banteng has received little conservation attention and in Java, it locally compete with more charismatic species such as Javan rhinoceros (Rhinoceros sondaicus).

The natural history and conservation needs of many tropical forest ungulates such as banteng are poorly known despite the important functional roles of such species within the ecosystems, such as shaping vegetation structure through herbivory (Bowman and Panton 1991; Djufri and Wardiah 2017), dispersing seeds through their roles as mixed feeders (Matsubayashi et al. 2007; Gardner et al. 2014), preys for medium to large carnivores (Pudyatmoko et al. 2007; Rahman et al. 2018), and protecting habitats from invasive species (Pearse and Hipp 2014). Such knowledge are essential, given that tropical forest ungulates are strongly affected by various threats from natural disturbances as well as human activities (Di Marco et al. 2014). In addition, there is a tendency that the conservation status of large-bodied species like banteng, deteriorated significantly more than the small-bodied species (Di Marco et al. 
2014) and lack of knowledge on the species' bio-ecological aspects will aggravate this situation. For this reason, understanding the ecological niche and factors that promote banteng's distribution is essential to develop proper conservation plans and determine the management strategies to ensure its persistence in this increasingly human-dominating landscape.

Spatial modelling is increasingly being used to study the ecological niches and distributions of various species (Wiens et al. 2009; Guisan et al. 2013; Lewis et al. 2017; Drouilly et al. 2018). One of the most popular species distribution modelling that uses presence-only data for inferring species distributions, habitat use, and environmental cues is the Maximum Entropy Modelling (Maxent; Phillips et al. 2006). This model allows users to fit models of arbitrary complexity (Warren and Seifert 2011; Rahman et al. 2017). Like many other tropical forest animals, banteng is difficult to monitor because of their elusive bahaviour. Using the presence records from camera traps, this study applied Maxent to model the habitat use and predict the potential distributions of banteng in Ujung Kulon National Park (UKNP). Use of camera traps to monitor terrestrial rare and cryptic animals in UKNP was initiated in 2011. This study was conducted to test the following hypotheses: i) banteng is highly dependent on primary and secondary forests compare to other forest types, and ii) undisturbed protected forest areas are essential for banteng conservation.

\section{Materials and methods}

Study areas. The study was conducted within the $323.24 \mathrm{~km}^{2}$ Core Zone of UKNP. The National Park is located in the Java Sea of Banten Province in Indonesia $\left(-6^{\circ} 45^{\prime} \mathrm{S} ; 105^{\circ} 20^{\prime} \mathrm{E}\right.$, Figure 1) and represents a remnant of ancient lowland tropical rainforest that have survived the 1883 eruption of Krakatau supervolcano and tsunami (Hommel 1987; Fauzi and Stoops 2004). Even currently, the area still faces a significant threats of natural catastrophes by earthquakes and tsunamis (Giachetti et al. 2012), zoonotic diseases by livestock (Tiuria et al. 2008), and reduced forest diversity by the invasion of Arenga obtusifolia palm (Hariyadi et al. 2012). The study area was primarily comprised of low-to-mid elevation tropical forest, which has suffered some natural and anthropogenic modifications, ranged between 0 and 620 masl, and experienced a tropical maritime climate with a mean annual rainfall 3,250 $\mathrm{mm}$. The heaviest rainfall occurred during the north-west monsoon from November to April, preceding a noticeably drier period with ca. $100 \mathrm{~mm}$ per month during the southeast monsoon from May to October. The mean monthly temperature varies between $25{ }^{\circ} \mathrm{C}$ and $30{ }^{\circ} \mathrm{C}$ with relative humidity ranged between $65 \%$ and $100 \%$ (Hommel 1987). According to the UKNP Vegetation Map, the area is covered by dense rainforest and composed of a mosaic of four main vegetation types: primary forest, secondary forest, mangrove-swamp, and beach forest (Appendix 1). At least eight large-medium sized mammal are known to co-exist, which include six ungulate species (Rhinoceros sondaicus, Bos

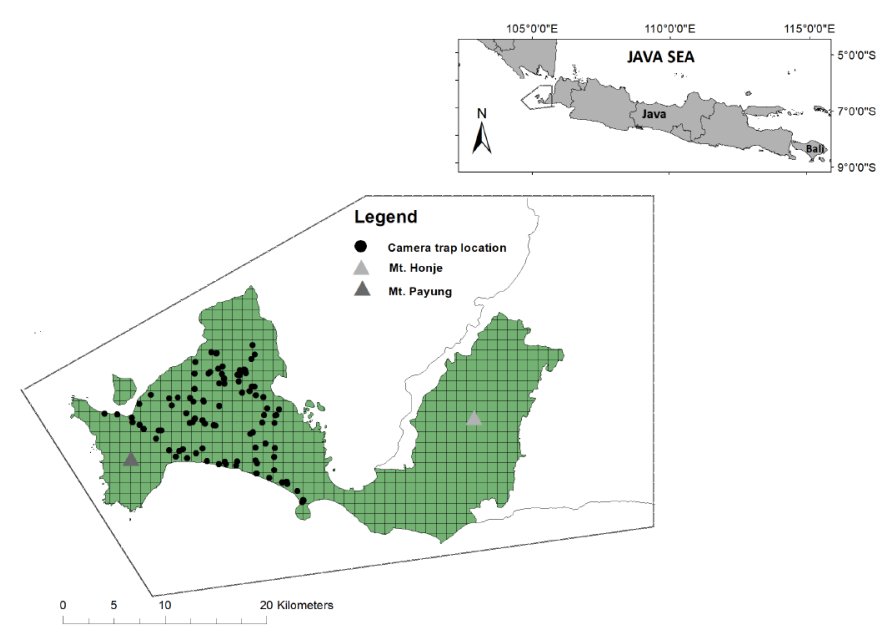

Figure 1. Camera trap locations in Ujung Kulon National Park (Indonesia).

javanicus, Rusa timorensis, Muntiacus muntjak, Sus scrofa, Sus verrucosus), felid (Panthera pardus melas), and canine (Cuon alpinus). However, in the past, these species faced varying degrees of threats from natural disasters and illegal human activities such as forest clearance, which have also led to the recent extirpation of some of these species (Hariyadi et al. 2012; Rahman et al. 2017). In UKNP, commercial poaching impacts might be minimal, resulted from the raised levels of active law enforcement patrols.

Sampling design. A $329 \mathrm{~km}$ grid was superimposed over the study area and almost half of the park was sampled (134 km grid). Single cameras were placed as close as possible to each intersection between the horizontal and vertical lines which comprised the grid (Figure 1). A total of 108 Bushnell Trophy camera traps (Model \#119405 and 119467) were operated between the months of December 2015 to January 2017 to detect animals over the 24 hours, followed by a 60 seconds video for each trigger. The time between successive triggers was set to 10 seconds. No cameras were baited and all videos were stamped with the date and time of recording. Cameras were set at 170 $\mathrm{cm}$ above the ground with a 10 to 20 degree angle leading to the ground (following the standard design of camera trapping by Rhino Monitoring Unit [RMU] team). All photographs were checked manually and encountered with mammals identified to species by the author. The camera traps were moved within the same grid when they did not capture any animal (zero presence) after two or three checking visits. Each photographed animal was identified to species. Sequential frames of the same species were counted as one photographic event, and unless individual identification was possible, any subsequent photograph of the same species taken within 30 minute interval would not be considered as a new photographic event or known as independent photographs. Location of each photograph was recorded using the latitude and longitude coordinate system and converted into digital data in GIS using ArcMap programme. Data were managed using camtrapR software (Niedballa et al. 2016). 
Relative Abundance Indices. Relative Abundance Indices (RAls) were used to report number of animal detections. To compute the RAl, all detections were summed for all camera traps over all days, multiplied by 100 , and divided by the total number of camera trap nights (O'Brien et al. 2003). The RAI was calculated as the number of photo captures per 100 trap nights to allow comparisons of each grid cells within the same season and using Chi-square tests to test differences between seasons.

Species distribution modeling and validation. Presence data of banteng was used to model the ecological niche and potential distributions. As many as 18 variables were considered as determinants of banteng's distributions in UKNP of which 14 accounted for environmental traits (vegetation, geomorphology, predation, and climate), and four accounting for human impacts (settlement, cultivated area, road, and illegal activity), the details are given in Appendix 2.

A distance raster was created using the Euclidean distance tool that measured the distance of each pixel to the nearest primary or secondary forest edge, river, presence of C. alpinus or P. Pardus melas, settlement, cultivated land, road, and illegal activity. Hereinafter, the distance value was extracted in ArcGIS 10.2.2 (ESRI; Phillips 2008). All distances were obtained from the Badan Kordinasi Survei dan Pemetaan Nasional (http://www.bakosurtanal.go.id/bakosurtanal/peta-rbi). Values for the other environmental variables were automatically extracted from the raster of each of camera trap'location. Environmental layers were created using Maxent software (Phillips et al. 2006). For any predict-
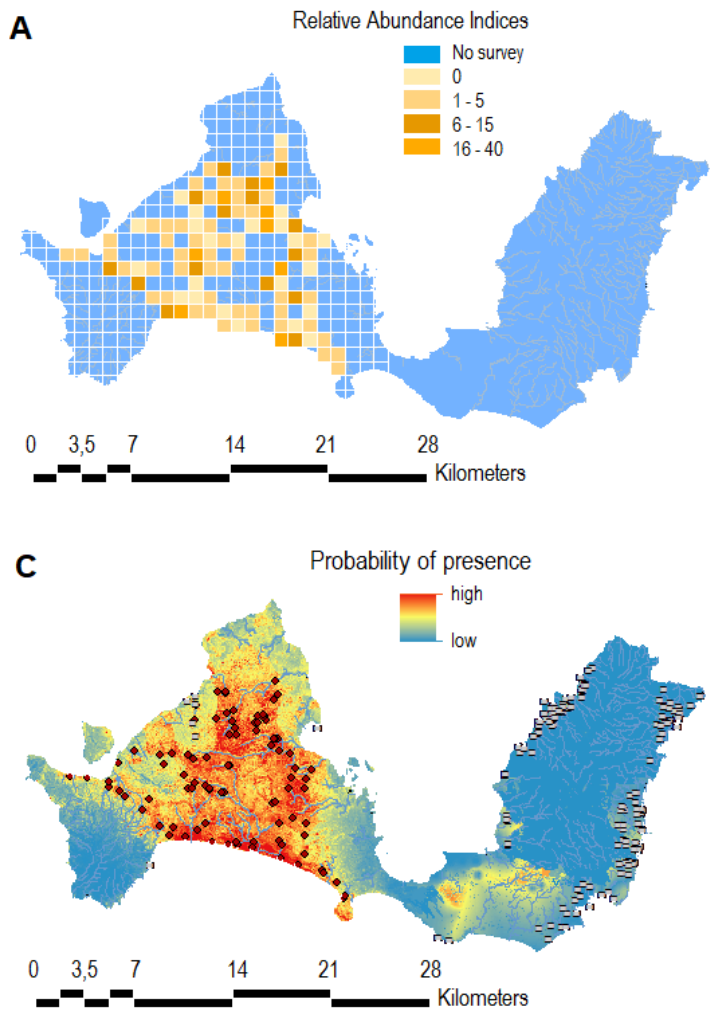

ing Maxent model, all rasters were re-sampled to a $100 \mathrm{~m}$ grid cell size and a mask layer was created from the park's boundaries to restrict the analysis to the study area (Young et al. 2011).

For all combinations of the environmental variables, Pearson's correlation coefficient was used to check for multicollinearity that might have resulted in over-parameterization and reduced the predictive power and interpretability (Morueta-Holme et al. 2010). Such provided the variables used in the final dataset: distance to primary forest edge, distance to secondary forest edge, Normalized Difference Vegetation Index (NDVI), elevation, slope, distance to river, distance to presence of $C$. alpinus and P. pardus melas, annual rainfall, annual mean temperature, distance to settlement, distance to cultivated land, distance to road, distance to illegal activity (Appendix 3).

This study used the following Maxent v.3.3.3k settings: automatic feature selection, a regularization multiplier at unity, maximum of 500 iterations, 50 replicates, and a convergence threshold of $10^{-5}$. This study also used a random test percentage of $10 \%$. In total, 100 pseudo-absences were randomized in the study area for the construction of the confusion matrix. A map of the potential distribution of the species was constructed using the logistic output, and the programme was run with "auto features" check (Phillips and Dudík 2008). The accuracy assessment of each model was measured using the Area Under The Curve (AUC) from the Receiver Operating Characteristic (ROC) curve (Woodward 1999; Thuiller 2003).
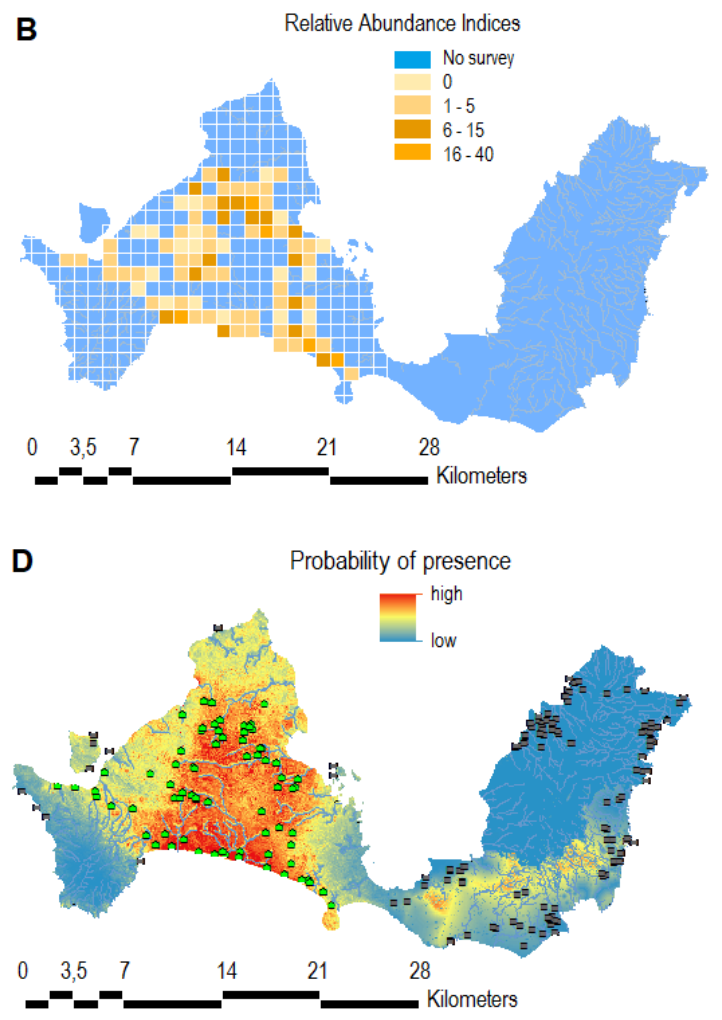

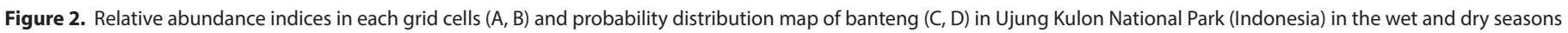

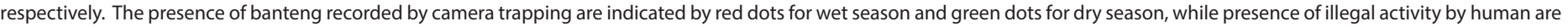
indicated by light grey squares for wet season and by dark grey squares for dry season. 
Table 1. The Area Under the Curve (AUC) and standard deviation for species model in two season at Ujung Kulon National Park. Number of independent photographs (NIP), Relative abundance index (RAI).

\begin{tabular}{lrrrr}
\hline \multicolumn{1}{c}{ Season } & \multicolumn{1}{l}{ NIP } & \multicolumn{1}{c}{ RAI } & \multicolumn{1}{c}{ AUC } & Standard deviation \\
\hline Wet & 779 & 4.67 & 0.835 & 0.053 \\
Dry & 644 & 4.79 & 0.899 & 0.065 \\
\hline
\end{tabular}

Variable contribution and response curve. This study used relative contribution and permutation importance as well as Jackknife test to assess the contributions of each environmental variable to the models (Phillips and Dudik 2008).

\section{Results}

Relative abundance indices (RAls). This study recorded as many as 3,199 photographs of banteng with 779 independent photographs during the wet season $(\mathrm{RAI}=4.67)$ and 645 during the dry season $(\mathrm{RAI}=4.78)$. Differences between the seasons were insignificant $(x 2=0.1985, \mathrm{~d}$. f. $=1, P>0.05)$. The highest RAI values both for the wet and dry seasons, were found within the core zone of UKNP (Figure 2A, B).

Species distribution modeling and validation. Areas predicted by the models as having high suitability conditions for banteng, were found almost on the entire park, except the high mountainous area at the southwest in both seasons (Figure 2C, D). All AUC values exceeded 0.835, indicating well-performed distribution models for banteng in each season (Table 1; Figure 3A, B).

Significant explanatory variables. Results of the habitat modelling, suggested that distance to the presence of Cuon

A

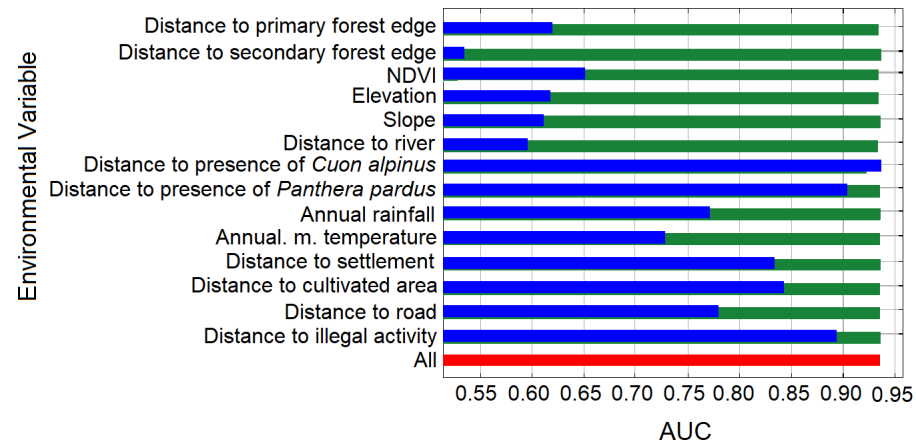

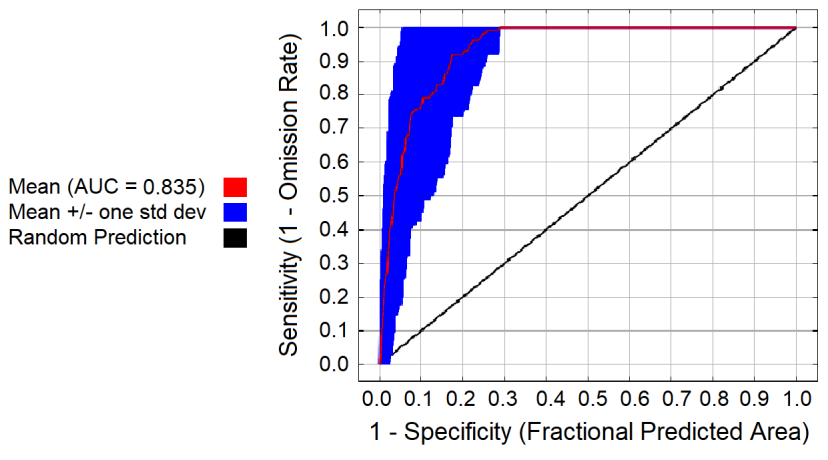

C

AUC alpinus was the most influential variable on the presence of banteng in a particular location, both in the wet and dry seasons $(23.50 \%$ and $21.70 \%$, respectively, Table 2$)$ followed by distance to the nearest illegal activity $(18.00 \%$ and $19.70 \%$, respectively). Similarly, based on permutation importance, distance to the presence of Cuon alpinus was the most significant both in the wet and dry seasons ( $24.20 \%$ and $24.90 \%$, respectively) followed by distance to the nearest illegal activity (9.80\% and $19.00 \%$, respectively). Distances to secondary forest edge and cultivated area were also shown to have positive influences on the banteng's occurrence contrary to distances to the presence of Cuon alpinus and illegal activity. The response curves were roughly unimodal for distance to secondary forest edge and bimodal for distance to the cultivated area during both seasons (Appendix 1, B2). Jackknife test suitability model showed the highest gain when "distance to the presence of Cuon alpinus" was used alone, while "distance to secondary forest edge" mostly increased the gain when it was omitted (Figure 3C, D).

\section{Discussion}

This study provided the first camera trap photographic analysis and presented an extensive dataset of banteng occurring in the UKNP, south-western Java. For more than two decades, the focus of the national park's management and various studies have been on the conservation of the Javan rhinoceros. The first unexpected result revealed by this study, was the quite large number of recorded ban-

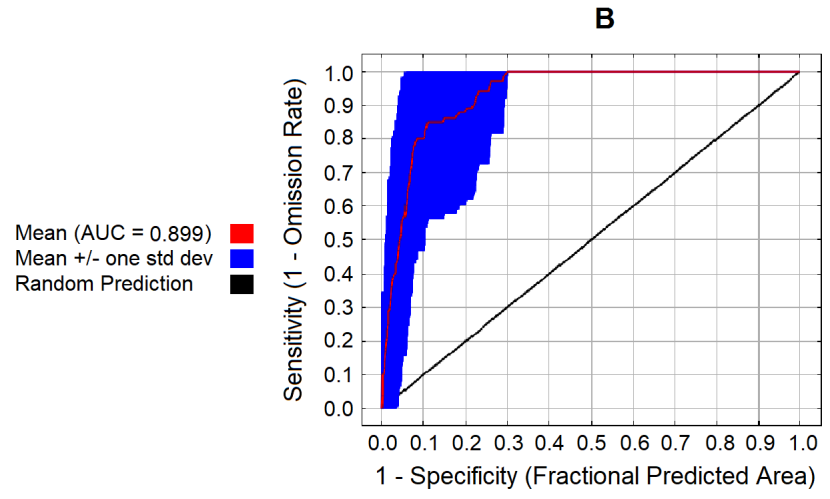

D

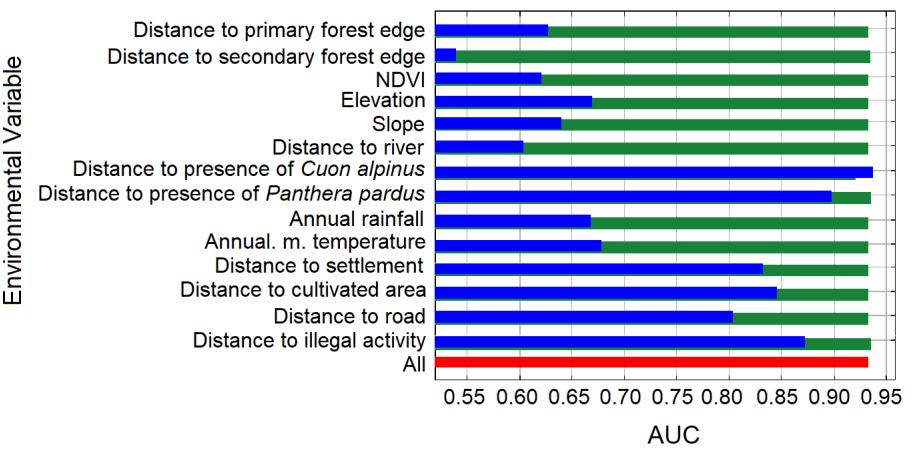

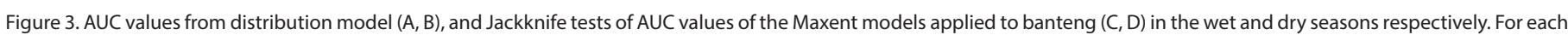

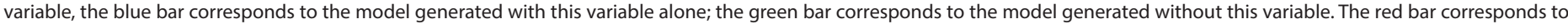
the model generated with all variables. 
teng photographs, as this species is cryptic, i. e., difficult to observe in the forest and considered to be rare in their natural habitat, particularly in the four remaining parks. Although data in this study were restricted to a single national park on the south-western tip of Java Island, the robust sampling design and the variety of surveyed habitats supported these results. Such provided essential basic knowledge for other areas of Java and the whole species' ranges. This measure is useful in a rapid assessment of the concentration sites occupied by the banteng.

The number of photographs per camera trap effort was much higher in the dry season, possibly related to a higher level of activity or more probably due to lower food availability. The abundance of food is inversely related to the proportion of time spent by animals to search and obtain food (Chappell 1980). Even if in most tropical forest, food is available throughout the year (Waide 2008), but in UKNP, it becomes less available during the dry season. This relative scarcity has lead to the broad movements of herbivores species and increases the probability of encounter (Rahman et al. 2017).

This study showed that banteng had strong preferences over forests located in lowland areas with high productivity of primary food source. Similar results were found among the banteng populations in Huai Kha Khaeng Wildlife Sanctuary of Western Thailand, where the species strictly uses lowland valleys of 160 to 600 masl (Prayurasithi 1987) and the population at Xe Plan Biodiversity Conservation Area in Laos (Steinmetz 2004). However, not all parts of the forest are occupied or preferred by banteng. Most of the population are concentrated away from the cultivation areas and settlements, which are far from human disturbances and

Table 2. The Relative Contribution (RC) and Permutation Importance (PI) of each environmental variable for each species as an average over the 50 replicates. Values are normalized to give percentages.

\begin{tabular}{lrrrr}
\hline \multicolumn{1}{c}{ Environmental variable } & \multicolumn{2}{c}{ Wet season } & \multicolumn{2}{c}{ Dry season } \\
& RC & PI & RC & PI \\
\hline Distance to primary forest edge & 5.70 & 4.50 & 1.20 & 0.70 \\
Distance to secondary forest edge & 17.00 & 21.30 & 17.50 & 14.80 \\
NDVI & 0.10 & 0.30 & 0.80 & 1.50 \\
Elevation & 11.30 & 20.30 & 8.00 & 8.60 \\
Slope & 2.40 & 3.30 & 0.10 & 0.40 \\
Distance to nearest river & 1.20 & 2.60 & 1.90 & 6.00 \\
Distance to presence of Cuon alpinus & 23.50 & 24.20 & 21.70 & 24.90 \\
Distance to presence of Panthera pardus & 2.90 & 0.90 & 1.90 & 0.80 \\
Annual rainfall & 4.90 & 1.90 & 8.10 & 8.00 \\
Annual mean temperature & 2.80 & 2.80 & 3.50 & 0.00 \\
Distance to nearest settlement & 3.20 & 2.10 & 3.00 & 1.70 \\
Distance to nearest cultivated area & 6.80 & 5.60 & 8.40 & 13.40 \\
Distance to nearest road & 0.20 & 0.40 & 4.20 & 0.20 \\
Distance to illegal activity & 18.00 & 9.80 & 19.70 & 19.00 \\
\hline
\end{tabular}

have the least disturbed forest cover and fewest human presence (Pudyatmoko 2005). It seemed that abundance of food, low human pressure, and low level of predation by Cuon alpinus, offered the most optimum habitat for banteng. As regrowth of dominant fruit tree canopies is found to be abundant in secondary forest areas, their structures may be atractive to several species of herbivorous mammals (Brown and Lugo 1990; García-Marmolejo et al. 2015). Rahman et al. (2017) found that such structure supports the habitat needs of muntjac (Muntiacus muntjak), one of the main herbivorous mammals in UKNP. This study found that fruits, buds, soft leaves, flowers, bamboo and young grass were consumed by banteng as their daily dietary preferences. This result supported the previous findings by other researchers in Baluran National Park (Halder 1976; Pudyatmoko 2005), Alas Purwo (Pudyatmoko 2005) and Ujung Kulon (Hoogerwerf 1970; Pairah 2007) who concluded that the diets of banteng consists of grass, tree leaves, herbs, shrubs, twigs and fruits, and bark of certain tree species, as found in the faecal analysis and direct observations. Banteng can be classified as a mixed feeder that frequently forages in open grasslands, dry forest and on the edges of evergreen forests (Gardner et al. 2014). In Huai Kha Khaeng (Thailand), they utlilise up to 150 different plant species, such as bamboos, fruits, and leaves (Bhumpakphan and McShea 2011).

The primary and secondary forests that dominated in Ujung Kulon landscape, provided resources for cover and food for banteng. This research found that banteng occurrences were positively associated with forest cover. Furthermore, banteng benefitted directly from the secondary forest with regeneration of native plants. Banteng were likely to be more resilient and adaptable to life in recovered forests than previously suggested, as shown by their preferences for secondary forests in the Baluran National Park or Borneo areas (Gardner et al. 2014). Habitat protection from various threats especially human disturbance, would accelerate the recovery time of banteng populations than previously thought. They are known to be effective as seed dispersers (Matsubayashi et al. 2007) making them an essential parts of reforestation efforts. Along with the need of forest cover, in UKNP, palm (Arenga obtusifolia) tree density is also critical for banteng's habitat, as the fruits provided alternative source of food for the banteng especially during dry season. The central part of the national park has a high dominance of the invasive palm trees, yet it has the highest occupancy rate of banteng, which was estimated to be as much as a forest dominated areas.

The palm in the UKNP ecosystem was a part of the natural succession process that took place after the eruption of Mount Krakatau in 1883 (Putro 1997). Several studies have shown that invasion of this plant has reduced biodiversity in UKNP, both in flora and fauna (Putro 1997). Moreover, this plant has been identified as a potential limiting factor in the distribution of Javan rhinos because it prevented the growth of food plant species, thus created 
a nutrition-poor area in which rhinos roamed (Hariyadi et al. 2012). Although this invasive palm provides benefits for the banteng and other wild animals in UKNP, limiting the place where this invasive species grows is necessary. Controlling palm and other invasive plant species can potentially be used to improve the wild animals' accessibility to certain areas within the habitat, and this has been started since 1997 in UKNP.

However, a recent study indicated that red muntjac tends to come closer to cultivation areas close to the park, because agricultural crops are attractive especially in the dry season (Rahman et al. 2017). Banteng in this study seems to do the same and do not restrict their movements to the non-protected area. The immense potential of domestic animals associated with human settlements or the presence of livestock (domestic cattle and water buffalo) that were commonly seen grazing in adjacent areas or within the national park around the Honje mountains, have attracted the presence of banteng. Such interaction might lead to distrupted population health and transmission of diseases from domestic animals, humans and vice versa (Morand et al. 2014). Limiting grazing areas for livestock owned by local communities around protected area is needed, including do a joint routine patrols by park manager and local communities to minimize these threat.

The model suggested that the variable distance from the nearest settlement as human accessibility and human disturbance affecting banteng occurrences. Higher banteng's occurrences with greater distances from the settlement, might indicate the higher abundance and concentration of banteng's activities in these less disturbed areas. These results is in line with the study by Gardner et al. (2014), which shows that banteng in the tropical lowland dipterocarp forest of Sabah (Borneo) is more abundant in areas with limited human presence. High levels of human activities in the lowlands could indicate the lowest occupancy rate and detection of banteng. Also, banteng detection increased with distance to deforested areas, indicating that banteng avoided nearby sites with deforested areas. Banteng prefers habitats with forest cover, and they usually avoid areas with human activities (Pudyatmoko 2005; Gardner et al. 2014). All areas with no vegetation cover in the study area, were associated with human activities, including farmland, open grasslands for livestock, and near roads and settlements. In these areas, banteng were more susceptible to hunting. Other studies have shown that banteng and other hoofed species, avoid areas with higher hunting activity and in the long term, increased their nocturnality (Gardner et al. 2014; Lone et al. 2015; Gaynor et al. 2018). Although poaching were found to occur in several locations within the park, banteng were not the target, and based on the interviews with the local people, they were generally undisturbed. Bantengs were not hunted since they have caused little crop damage in the area. However, future agricultural expansion could increase potential human-banteng conflicts, as well as potential of transmitted diseases as described previously.

Dhole (Cuon alpinus) has a significant negative interaction and overlapping habitat with banteng. In some captures, it is possible to see the banteng predation activity by dhole. A group of dhole were targeting a calf by separating from its mother. On the other hand, dhole is almost entirely a diurnal hunter in UKNP as observed in another study by Nurvianto et al. ( 2015), probably due to the difficulties in coursing after fleet-footed prey in dense cover in darkness. Dholes have the advantage of large-sized prey hunts because they are living in groups (Rahman et al. 2019). The dhole's activity also overlaps with wild boar, but the level of consumption of wild boar by dholes is lower than with banteng (Kamler et al. 2012). This overlap is in agreement with the pattern of movement and distribution of herbivore animals, that are generally strongly associated with predators. Herbivores tend to adjust the movement through the avoidance strategy (Flaxman et al. 2011; Rosier and Langkilde 2011; Van Langevelde et al. 2013).

Other variables such as NDVI, elevation, slope, distance to river, annual temperature and annual precipitation were found to be insignificant, possibly because their variation were too small within the area studied or fell within the usual range for the banteng. The UKNP is an example of lowland tropical rainforest with low elevation and slope variation, which can reach to 800 masl (S. Hedges, press Comm. 2008). The increase showed a significant negative correlation with the presence of banteng (Namgyal and Thinley 2017). The positive effects of NDVI were found to be closely related to the herbivorous nature of the species because of their dependence on forests. From ca. $70 \%$ of all forest habitat types in the UKNP, secondary forest were highly dominant and strongly associated with the presence of herbivore animals.

There were many camera trap studies focused on the Javan rhinoceros, and banteng photographs are consistently recorded as by-products. To date, there has been little support for ungulates research targeted in Indonesia, hence it is often difficult to execute a large scale, and longterm individual studies on ungulates. This study provides an outline of research and analysis that was easily customisable for use across species ranges and in standard formats. The modelling framework presented here, provided interesting results, with notably high and stable AUC values which are common for the species specialist like bantengs. Furthermore, concerning the map of banteng distribution to demonstrate the modelling strategy, this study has shown that banteng's occupation area has been restricted in the Ujung Kulon Peninsula. This study provided valuable baseline information on habitat use of banteng in UKNP that would assist the park management to detect changes to make effective conservation decisions and measures. 
Moreover, one important thing to be noted is that habitat degradation and loss by natural catastrophes such as sea-level rise, cyclones, volcanic activity, and tsunami are still ongoing threats to banteng in UKNP (Yusuf and Francisco 2009). With the majority of the population concentrating in the centre and near the shoreline of the Ujung Kulon Peninsula, banteng and their preferred habitats are highly exposed to risks of tsunami lunge and inundation. Although annual probability predictions of an earthquake causing tsunami heights of greater than three metres at UKNP is relatively small, but over longer time-frames $(>100$ years), tsunamis of 30 metres are probable (Horspool et al. 2014). Recently, on December 2018, a tsunami caused by a landslide in the Sunda Strait following a massive eruption of the Anak Krakatau volcano, struck the western tip of Java and southern end of Sumatra. The tsunami generated waves up to five metres, some of which crashed ashore Ujung Kulon, which would threaten the majority of areas with high banteng density, potentially leading to drowning or considerable alteration of primary habitat. To significantly reduce banteng extinction risk in UKNP, human intervention and long-term investment will be necessary. These would include both, an increase in UKNP's carrying capacity through habitat management or food supplementation and establishing additional independent populations that are less exposed to tsunamis and other threats present at UKNP.

\section{Acknowledgments}

The author would like to thank the anonymous reviewers for their valuable comments and suggestions to improve the manuscript. Also, the author would like to thank R. Reyna and A. Sunkar for constructive criticism and giving improvement to the manuscript. Moreover, the author wishes to thank the team of Rhino Monitoring Unit (RMU) in Ujung Kulon National Park, Ministry of Environment and Forestry, the Republic of Indonesia who contributed to data collection.

\section{Literature cited}

Bhumpakphan, N., AND W. J. McShea. 2011. Ecology of gaur and banteng in the seasonally dry forests of Thailand. Pp. 179-194 in The Ecology and Conservation of Seasonally Dry Forests in Asia (McShea, W. J., S. J. Davies, and N. Bhumpakphan, eds.). Smithsonian Institution Scholarly Press. Washington, U.S.A.

Bowman, D. M. J. S., AND W. J. Panton. 1991. Sign and habitat impact of banteng (Bos javanicus) and pig (Sus scrofa), Cobourg Peninsula, northern Australia. Austral Ecology 16:15-17.

Brown, S., AND A. E. Lugo. 1990. Tropical secondary forests. Journal of Tropical Ecology 6:1-32.

Chappell, M. A. 1980. Thermal energetic and thermoregulatory costs of small arctic mammals. Journal of Mammalogy 61:278-291.

Di Marco, M., L. Boitani, D. Mallon, M. Hoffmann, A. Iacucci, E. MeijaArd, P. Visconti, J. Schipper, and C. Rondinini. 2014. A retrospective evaluation of the global decline of carnivores and ungulates. Conservation Biology 28:1109-18.

DJufri., AND Wardiah. 2017. The diversity of undergrowth plants on Acacia nilotica stands as food resources of banteng (Bos javanicus) in Baluran National Park, East Java, Indonesia. Biodiversitas 18:288-294.

Drouilly, M., A. Clark, and M. J. O'Riain. 2018. Multispecies occupancy modelling of mammal and ground bird communities in rangeland in the Karoo: A case for dryland systems globally. Biological Conservation 224:16-25.

Fauzl, A. I., AND G. Stoops. 2004. Reconstruction of a toposequence on volcanic material in the Honje Mountains, Ujung Kulon Peninsula, West Java. Catena 56: 45-66.

Flaxman, S. M., Y. Lou, and F. G. Meyer. 2011. Evolutionary ecology of movement by predators and prey. Theoretical Ecology 4:255-267.

Frankie, G. W., P. A. Opler, and H. G. Baker. 1974. Comparative phenological studies of trees in wet and dry forests in the lowlands of Costa Rica. Journal of Ecology 62:881-919.

García-Marmolejo, G., L. Chapa-Vargas, M. Weber, and E. Huber-Sannwald. 2015. Landscape composition influences abundance patterns and habitat use of three ungulate species in fragmented secondary deciduous tropical forests, Mexico. Global Ecology and Conservation 3:744-755.

Gardner, P. C., S. Pudyatmoko, N. Bhumpakphan, M. Yindee, D. L. N. Ambu, ANd B. Goossens. 2014. Banteng Bos javanicus d'Alton, 1823. Pp. 216-230 in Ecology, Evolution and Behaviour of Wild Cattle: Implications for Conservation (Melletti M. and J. Burton, eds.). Published by Cambridge University Press. Cambridge, U.K.

Gaynor, K. M., C. E. Hojnowski, N. H. Carter, and J. S. Brashares. 2018. The influence of human disturbance on wildlife nocturnality. Science 360:1232-1235.

Giachetti, T., R. Paris, K. Kelfoun, and Ontowirjo. 2012. Tsunami hazard related to a flank collapse of anak Krakatau Volcano, Sunda Strait, Indonesia. Geology Society 361:79-90.

Goverment of Indonesia. 1999. Peraturan Pemerintah Republik Indonesia Nomor 7 Tahun 1999 tentang pengawetan jenis tumbuhan dan satwa. Jakarta, Indonesia.

Guisan, A., R. Tingley, J. B. Baumgartner, I. NaujokaitisLewis, P. Sutcliffe, A. I. T. Tulloch, T. J. Regan, L. Brotons, E. McDonald-Madden, C. Mantyka-Pringle, T. G. Martin, J. R. Rhodes, R. Maggini, S. A. Setterfield, J. Elith, M. W. Schwartz, B. A. Wintle, O. Broennimann, M. Austin, S. Ferrier, M. R. Kearney, H. P. Possingham, and Y. M. Buckley. 2013. Predicting species distributions for conservation decisions. Ecology Letters 16:1424-1435.

Halder, U. 1976. Ökologie und Verhalten des Banteng (Bos javanicus) in Java. Hamburg: Verlag Paul Parey. Hamburg and Berlin, Germany.

Hariyadi, A. R. S., A. Priambudi, R. Setiawan, Daryan, H. Purnama, AND A. Yayus. 2012. Optimizing the habitat of the Javan rhinoceros (Rhinoceros sondaicus) in Ujung Kulon National Park by reducing the invasive palm Arenga obtusifolia. Pachyderm 52:49-54.

HомmeL, P. W. F. M. 1987. Landscape Ecology of Ujung Kulon (West Java, Indonesia). Soil Research Institute, Wageningen, The Netherlands.

Hoogerwerf, A. 1970. Udjung Kulon, the Land of the Last Javan 
Rhinocheros. Leiden: E. J. Brill. Jakarta, Indonesia.

Horspool, N., I. Pranantyo, J. Griffin, H. Latief, D. H. Natawidjaja, W. Kongko, A. Cipta, B. Bustaman, S. D. Anugrah, and H. K. Thio. 2014. A probabilistic tsunami hazard assessment for Indonesia. Natural Hazard and Earth System Sciences 14:3105-3122.

Kamler, J. F., U. Klare, And D. W. MacDonald. 2012. Seasonal diet and prey selection of black-backed jackals on a small-livestock farm in South Africa. African Journal of Ecology 48:847-848.

Lewis, J. S., M. L. Farnsworth, C. L. Burdett, D. M. Theobald, M. Gray, and R. S. Miller. 2017. Biotic and abiotic factors predicting the global distribution and population density of an invasive large mammal. Scientific Reports 7:44152.

Lone, K., L. E. Loe, L. E. Meisingset, I. Stamnes, and A. Mysterud. 2015. An adaptive behavioural response to hunting: surviving male red deer shift habitat at the onset of the hunting season. Animal Behaviour 102:127-138.

Matsubayashi, H., P. Lagan, ANd J. R. A. Sukor. 2007. Herbal seed dispersal by the banteng (Bos javanicus) in a Bornean tropical rain forest. Malayan Nature Journal 59:297-303.

Ministry OF Forestry. 1990. Undang-Undang Republik Indonesia Nomor 5 Tahun 1990 Tentang Konservasi Sumberdaya Alam Hayati dan Ekosistemnya. J akarta, Indonesia.

Ministry of Environment and Forestry. 2015. Keputusan Direktur Jenderal Konservasi Sumber Daya Alam dan Ekosistem No. SK. 180/IV-KKH Tahun 2015 Tentang Penetapan Dua Puluh Lima Satwa Terancam Punah Prioritas Untuk Ditingkatkan Populasinya Sebesar 10\%. Jakarta, Indonesia.

Morand, S., K. M. McIntyre, And M. Baylis. 2014. Domesticated animals and human infectious diseases of zoonotic origins: domestication time matters. Infection Genetic and Evolution 24:76-81.

Morueta-Holme, N., C. FløjgaARd, and J. C. Svenning. 2010. Climate change risks and conservation implications for a threatened small-range mammal species. PloS One 5:e10360.

Namgyal, C., and P. Thinley. 2017. Distribution and habitat use of the Endangered dhole Cuon alpinus (Pallas, 1811) (Mammalia: Canidae) in Jigme Dorji National Park, Western Bhutan. Journal of Threatened Taxa 9:10649-10655.

Niedballa, J., R. Sollmann, A. Courtiol, And A. Wilting. 2016. CamtrapR : an R package for efficient camera trap data management. Methods Ecology Evolution. 7:1457-1462.

Nurvianto, S., M. A. Imron, And S. Herzog. 2015. The influence of anthropogenic activities and availability of prey on the distribution of dholes in a dry deciduous forest of East Java, Indonesia. Asian Journal of Conservation Biology 4:26-36.

O'Brien, T. G., M. F. KinnaiRd, AND H.T.Wibisono. 2003. Crouching tigers, hidden prey: Sumatran tiger and prey populations in a tropical forest landscape. Animal Conservation 6:131-139.

Pairah. 2007. Tumpang tindih relung ekologis Banteng (Bos javanicus, d'Alton 1823) dan Rusa Timor (Rusa timorensis, Blainville 1822) di padang penggembalaan Sadengan, Taman Nasional Alas Purwo, Jawa Timur. MSc thesis. Fakultas Kehutanan Universitas Gadjah Mada. Bahasa, Indonesia.

Paris, R., P. Wassmer, F. Lavigne, A. Belousov, M. Belousova, Y. Iskandarsyah, M. Benbakkar, B. Ontowirjo, and N. Mazzoni. 2014. Coupling eruption and tsunami records: the Krakatau 1883 case study, Indonesia. Bulletin of Volcanology 76:814-836.

Pearse, I. S., And A. L. Hipp. 2014. Native plant diversity increases herbivory to non-natives. Proceedings of the Royal
Society London B: Biological Sciences 281:20141841.

Phillips, S. J., R. P. Anderson, And R. E. Schapire. 2006. Maximum entropy modelling of species geographic distribution. Ecological Modelling 190:231-259.

Philuips, S. 2008. A Brief Tutorial on Maxent. AT \& T Research, Florham Park, NJ. https://biodiversityinformatics.amnh.org/ open_source/maxent/Maxent_tutorial2017.pdf.

Phillips, S. J., AND M. Dudík. 2008. Modelling of species distributions with Maxent: new extensions and a comprehensive evaluation. Ecography 31:161-175.

Prayurasithi, T. 1987. Ecology of banteng in Huai Kha Khaeng Wildlife Sanctuary. MSc thesis. Kasetsart University.

Pudyatmoko, S. 2005. Freilanduntersuchungen zur Ökologie und Habitatnutzung Wildlebender Banteng Rinder (Bos javanicus) im Baluran National Park in Ost Java, Indonesien. Goettingen: Cuvillier Verlag, Indonesia

Pudyatmoko, S., Duuwantoko, and Y. Sabarno. 2007. Evidence of banteng (Bos javanicus) decline in Baluran National Park, Indonesia. Journal of Biological Sciences 7:854-859.

Putro, H. R. 1997. Invasi langkap (Arenga obtusifolia) dan dampaknya terhadap keanekaragaman hayati di Taman Nasional Ujung Kulon, Jawa Barat. Media Konservasi 95-100

Rahman, D. A., G. Gonzalez, M. Haryono, A. Muhtarom, A. Y. Firdaus, and S. Aulagnier. 2017. Factors affecting seasonal habitat use, and predicted range of two tropical deer in Indonesian rainforest. Acta Oecologica 82:41-51.

Rahman, D. A., P. Rianti, M. Muhiban, A. Muhtarom, U. M. Rahmat, Y. Santosa, and S. Auglanier. 2018. Density and spatial partitioning of endangered sympatric Javan leopard (Felidae) and dhole (Canidae) in a tropical forest landscape. Folia Zoologica 67:207-219.

Rahman, D. A., R. Herliansyah, P. Rianti, U. M. Rahmat, A. Y. Firdaus, ANd M. Syamsudin. 2019. Ecology and conservation of the Endangered banteng (Bos javanicus) in Indonesia tropical lowland forest. Hayati 26:68-80.

Rosier, R. L., And T. Langkilde. 2011. Behavior under risk: How animals avoid becoming dinner. Nature Education Knowledge 2:8.

Setiawan, R., B. D. Gerber, U. M. Rahmat, D. Daryan, A. Y. Firdaus, M. Haryono, K. O. Khairani, Y. Kurniawan, B. Long, A. Lyet, M. Muhiban, R. Mahmud, A. Muhtarom, E. Purastuti, W. S. Ramono, D. Subrata, And S. Sunarto. 2018. Preventing global extinction of the Javan rhino: tsunami risk and future conservation direction. Conservation Letters 11:e12366.

Steinmetz, R. 2004. Gaur (Bos gaurus) and banteng (Bos javanicus) in the lowland forest mosaic of Xe Pian Protected Area in Lao PDR: abundance, habitat use and conservation. Mammalia 68:141-157.

Thuiller, W., M. B. Araújo, and S. Lavorel. 2003. Generalized model vs. classification tree analysis: predicting spatial distributions of plant species at different scales. Journal Vegetation Science 14: 669-680.

Tiuria, R., J. Pangihutan., R. M. Nugraha., B. P. Priosoeryanto, And A. R., Hariyad.. 2008. Kecacingan trematoda pada badak jawa dan banteng jawa di Taman Nasional Ujung Kulon. Jurnal Veteriner 9:94-98.

Van langevelde, F., A. Van Woersem W. F. de Boer, S. de Bie, R. Slotow, A. Burger, J. Swart, and H. H. T. Prins. 2013. Encounters with predators have a larger influence on 
the spatial distribution and movement of their prey than expected. 98th ESA Annual Convention. August 4-9. Minneapolis, U.S.A.

WAIDE, R. B. 2008. Tropical rainforest. In Encyclopedia of Ecology 3625-3629. Elsevier, Amsterdam, Netherlands.

Warren, D. L., and S. N. Seifert. 2011. Ecological niche modeling in Maxent: the importance of model complexity and the performance of model selection criteria. Ecological Applications 21:335-342.

Wiens, J. A., D. Stralberg, D. Jongsomjit, C. A. Howell, and M. A. Snyder. 2009. Niches, models, and climate change: Assessing the assumptions and uncertainties. PNAS 106:19729-19736.

Woodward, M. 1999. Epidemiology: Study Design and Data Analysis. Chapman \& Hall, London, U.K.

Young, N., L. Carter, and P. Evangelista. 2011. A Maxent model v3.3.3e tutorial (ArcGIS v10). Natural Resource Ecology Laboratory at Colorado State University and the National Institute of Invasive Species Science. Fort Collins, U.S.A.

Yusuf, A. A, and H. Francisco. 2009. Climate change vulnerability mapping for Southeast Asia. Economy and Environment Program for Southeast Asia (EEPSEA), Singapore, Republic of India.

Associated editor: Guillermo D'Elía

Submitted: June 3, 2019; Reviewed: August 8, 2019;

Accepted: November 18, 2019; Published on line: December 27, 2019. 


\section{Appendix 1}

\section{Primary forest}

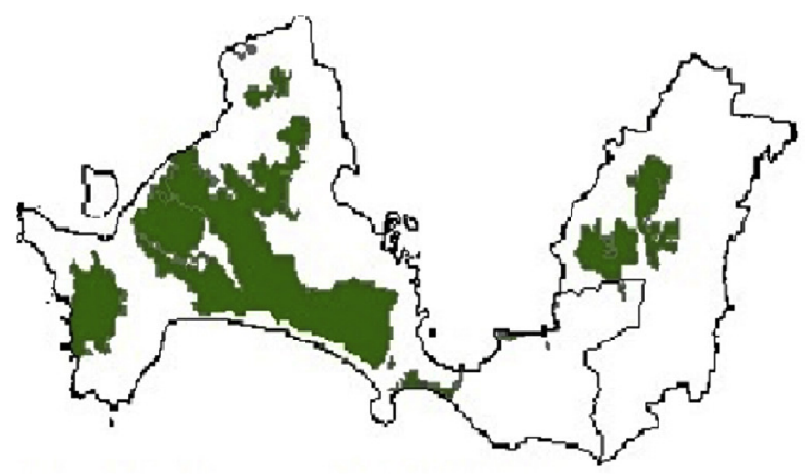

$\begin{array}{lll}0 & 510 \quad 20 \text { Kilometers }\end{array}$

\section{Mangrove - swap}

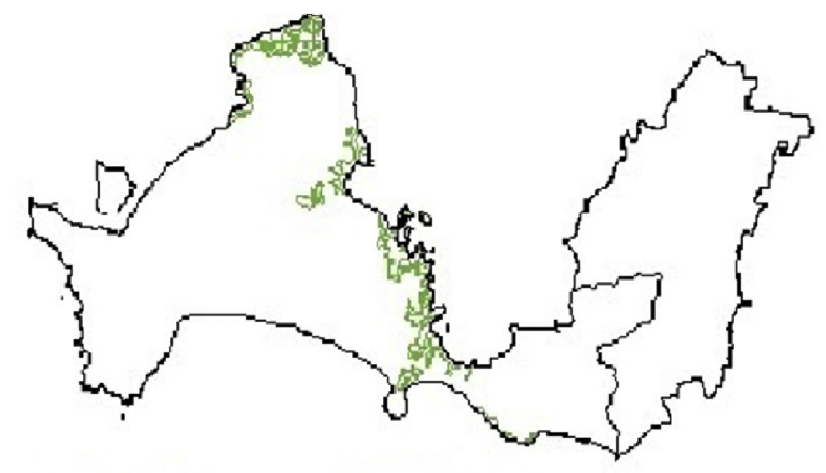

O $510 \quad 20$ Kilometers

\section{Secondary forest}

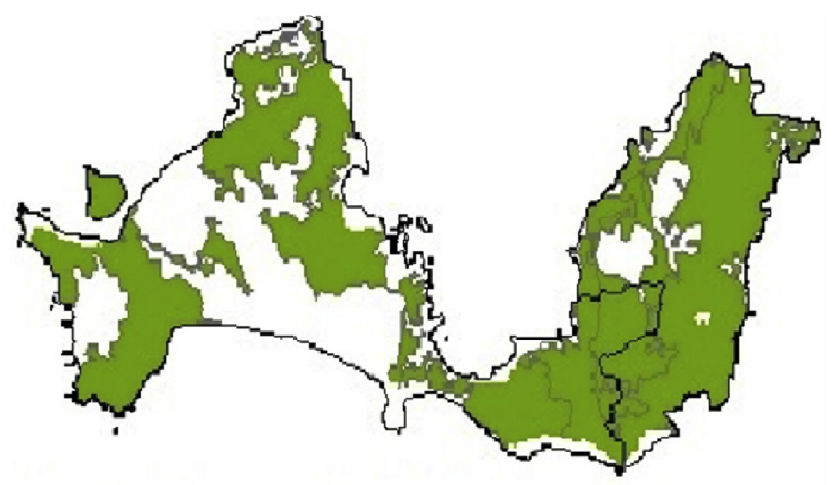

$0510 \quad 20$ Kilometers

\section{Beach forest}

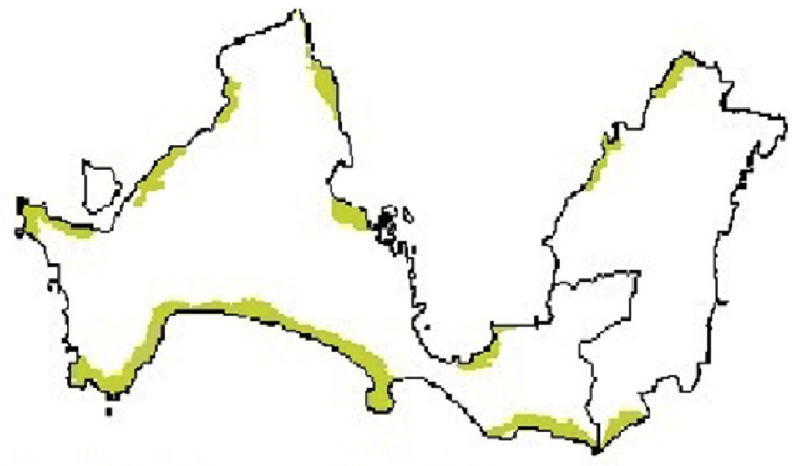

0 $510 \quad 20$ Kilometers 


\section{Appendix 2}

The environmental variables was considered to influence banteng distribution in Ujung Kulon National Park

\begin{tabular}{|l|l|l|}
\hline \multicolumn{1}{|c|}{$\begin{array}{c}\text { Environmental variables } \\
\text { classification }\end{array}$} & \multicolumn{1}{|c|}{ Variables } & \multicolumn{1}{c|}{ Measured analysis } \\
\hline Vegetation variables & $\begin{array}{l}\text { Distance to primary and secondary forest edge, } \\
\text { and vegetation productivity }\end{array}$ & $\begin{array}{l}\text { Distance to the primary and secondary forest edge were extracted in ArcGIS 10.2.2, whilst vegetation } \\
\text { productivity measured as the normalized difference vegetation index (NDVI, cf. Hansen et al. 2009) }\end{array}$ \\
\hline Geomorphology variables & Elevation, slope and distance to nearest river & $\begin{array}{l}\text { The first two variables were computed on a 1 km² grid resolution by averaging information } \\
\text { extracted from a } 90 \times \text { x } 90 \mathrm{~m} \text { Digital Elevation Model (DEM; Landsat 8 (http://earthexplorer.usgs.gov; } \\
\text { http://srtm.csi.cgiar.org). Slopes were generated using slope function in ArcGIS (Jarvis et al. 2008). } \\
\text { Distance to the nearest river was extracted in ArcGIS 10.2.2 }\end{array}$ \\
\hline Predation & $\begin{array}{l}\text { Distance to the nearest presence of C. alpinus } \\
\text { and P.pardus melas }\end{array}$ & Distance to the nearest presence of C. alpinus and P. pardus melas were extracted in ArcGIS 10.2.2 \\
\hline Climate variables & $\begin{array}{l}\text { Annual rainfall, rainfall of the wettest month, } \\
\text { rainfall of the driest month, annual mean } \\
\text { temperature, the maximum temperature of the } \\
\text { warmest month, and minimum temperature of } \\
\text { the coldest month }\end{array}$ & $\begin{array}{l}\text { These variables, derived from monthly temperature and rainfall values recorded between } 1950 \text { and } \\
\text { (http://worldclim.org/bioclim). All layers were projected into WGS 1984 Zone 48 South }\end{array}$ \\
\hline Human impact variables & $\begin{array}{l}\text { Distance to the nearest settlement, cultivated } \\
\text { area, road, and illegal activity by human }\end{array}$ & $\begin{array}{l}\text { Distance to the nearest settlement, cultivated area, road, and illegal activity by human were } \\
\text { extracted in ArcGIS 10.2.2 }\end{array}$ \\
\hline
\end{tabular}

Hansen, B. B., I. Herfindal, R. Aanes, B. E. Saether, and S. HenkiKsen. 2009. Functional response in habitat selection and the tradeoffs between foraging niche components in a large herbivore. Oikos, 118: 859-872.

Jarvis, A., H. I. Reuter, A. Nelson, and E. Guevara. 2008. Hole-filled SRTM for the Globe Version 4, Available from the CGIAR-csi SRTM 90m Database. Available at: http://srtm.csi.cgiar. org. 


\section{Appendix 3}

Pearson's correlations between the environmental variables used in the distribution modeling for banteng in Ujung Kulon National Park.

\begin{tabular}{|c|c|c|c|c|c|c|c|c|c|c|c|c|c|c|c|c|c|c|}
\hline$\frac{\frac{n}{0}}{\frac{0}{0}}$ & 方 & $\begin{array}{l}\frac{c}{0} \\
\stackrel{0}{\pi} \\
\frac{\pi}{\omega}\end{array}$ & $\frac{\dddot{0}}{\sim}$ & 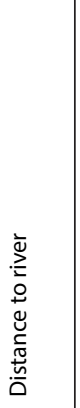 & 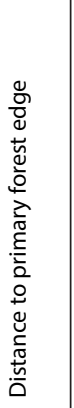 & 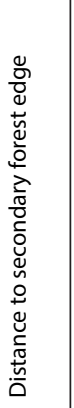 & 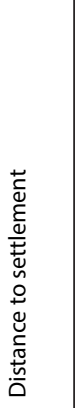 & 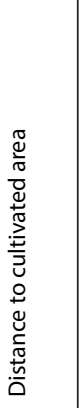 & 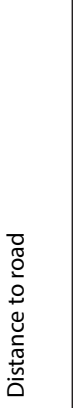 & 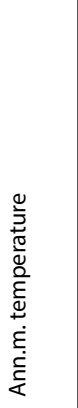 & 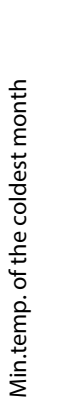 & 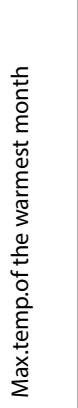 & 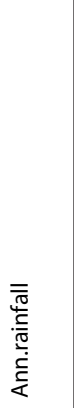 & 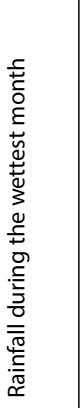 & 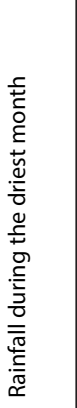 & 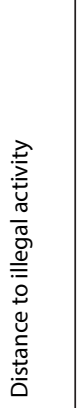 & 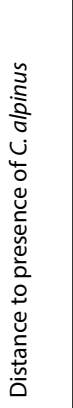 & 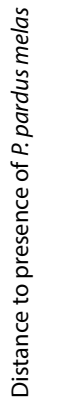 \\
\hline NDVI & 1 & & & & & & & & & & & & & & & & & \\
\hline Elevation & -.008 & 1 & & & & & & & & & & & & & & & & \\
\hline Slope & -.032 & $.195^{* *}$ & 1 & & & & & & & & & & & & & & & \\
\hline Distance to river & -.067 & $.242^{* *+}$ & -.091 & 1 & & & & & & & & & & & & & & \\
\hline Distance to primary forest edge & .094 & $-.499^{* *}$ & $-.217^{* *}$ & .015 & 1 & & & & & & & & & & & & & \\
\hline Distance to secondary forest edge & -.040 & $.513^{* *}$ & -.059 & $.333^{* *}$ & $-.329^{*+*}$ & 1 & & & & & & & & & & & & \\
\hline Distance to settlement & .039 & $.508^{* *}$ & $.155^{*}$ & .024 & $-.560^{* *}$ & $.240^{* *}$ & 1 & & & & & & & & & & & \\
\hline Distance to cultivated area & .038 & $.514^{* *}$ & $.122^{*}$ & .039 & $-.553^{* *}$ & $.217^{* *}$ & $.388^{* *}$ & 1 & & & & & & & & & & \\
\hline Distance to road & .049 & $.517^{* *}$ & $.116^{*}$ & .044 & $-.514^{* *}$ & $.243^{* *}$ & $.503^{* *}$ & $.070^{* *}$ & 1 & & & & & & & & & \\
\hline Ann.mean temperature & -.013 & $-.512^{* *}$ & $-.144^{*}$ & $-.180^{*}$ & $.580^{* *}$ & $-.530^{* *}$ & $-.561^{*}$ & $-.540^{* *}$ & $-.542^{* *}$ & 1 & & & & & & & & \\
\hline Min.temp. of the coldest month & .033 & $-.917^{* *}$ & $-.150^{*}$ & $-.165^{* *}$ & $.622^{* *+}$ & $-.513^{* *}$ & $-.524^{* *}$ & $-.478^{* *}$ & $-.477^{* *}$ & $.976^{* *}$ & 1 & & & & & & & \\
\hline Max.temp. of the warmest month & .010 & $.022^{* *}$ & $-.156^{*}$ & $-.163^{* *}$ & $.619^{* *}$ & $-.528^{* *}$ & $-.628^{* *}$ & $-.575^{* *}$ & $-.545^{* *}$ & $.989^{* *}$ & $.677^{* *}$ & 1 & & & & & & \\
\hline Ann.rainfall & -.078 & $.050^{* *}$ & $.166^{*}$ & $.144^{*}$ & $-.544^{* *}$ & $.480^{* *}$ & $.266^{* *}$ & $.228^{* *}$ & $.222^{* *}$ & $-.680^{* *}$ & $-.443^{* *}$ & $-.468^{* * *}$ & 1 & & & & & \\
\hline Rainfall during the wettest month & $-.186^{*}$ & $-.263^{* *+*}$ & .016 & $-.134^{*}$ & .044 & $-.168^{*}$ & $-.667^{* *}$ & $-.665^{*}$ & $-.686^{* *}$ & $.258^{* *}$ & -.822 & $.292^{* * *}$ & $.765^{* *}$ & 1 & & & & \\
\hline Rainfall during the driest month & .118 & $-.952^{* *}$ & .057 & $.236^{* *}$ & $-.354^{* *}$ & $.500^{* *}$ & $.529^{* *}$ & $.486^{*}$ & $.520^{* *}$ & $-.546^{*}$ & $-.553^{* *}$ & $-.751^{* *}$ & $.899^{* *}$ & $-.609^{* *}$ & 1 & & & \\
\hline Distance to illegal activity & -.013 & $-.512^{* *}$ & $-.144^{*}$ & $.619^{* *}$ & $-.528^{* *}$ & $-.628^{* *}$ & $-.575^{* *}$ & $-.545^{* * 1}$ & $.619^{* *}$ & .049 & $.517^{* *}$ & $.116^{*}$ & .044 & .010 & $.022^{* *+}$ & 1 & & \\
\hline Distance to presence of C. alpinus & -.065 & $.045^{* *}$ & $.187^{*}$ & $.166^{*}$ & $-.522^{*}$ & $.450^{* *}$ & .270 & $.233^{* *}$ & $.298^{* *}$ & -.540 & $-.333^{* *}$ & $-.548^{* *}$ & .094 & $-.499^{* *}$ & $-.217^{* *}$ & .015 & 1 & \\
\hline Distance to presence of $P$. pardus melas & -.088 & $.054^{* *}$ & $.169^{*}$ & $.146^{*}$ & $-.577^{*}$ & $.490^{* *}$ & $.266^{* * *}$ & $.256^{* *}$ & $.233^{*}$ & $-.677^{* *}$ & $-.413^{* *}$ & $-.488^{* *}$ & .049 & $.517^{* *}$ & $.116^{*}$ & .044 & $-.514^{* *}$ & \\
\hline
\end{tabular}

** Correlation is significant at the 0.01 level (2-tailed).

* Correlation is significant at the 0.05 level (2-tailed). 